\title{
KONFLIK TRANSPORTASI OJEK PANGKALAN DAN OJEK ONLINE DI BANDUNG (STUDI ANALISIS TENTANG IDENTITAS BUDAYA, MANAJEMEN KONFLIK, DAN TEKNOLOGI)
}

\author{
Diana Anggraeni \\ Fakultas Ilmu Komunikasi Universitas Pancasila \\ dachsp@cbn.net.id
}

\begin{abstract}
ABSTRAK
Tujuan dari penelitian ini adalah untuk mengetahui dan menganalisa bagaimana sebuah kemajuan dalam teknologi informasi menghasilkan sebuah budaya baru dalam moda transportasi yang kemudian membentuk potensi konflik lintas budaya dengan pola konsumsi penggunaan trasnportasi yang sudah ada sejak lama dalam hal ini ojek pangkalan dengan ojek online. Studi ini berusaha menjelaskan, mendeskripsikan dan menganalisa konflik yang terjadi didasarkan pada pemberitaan di Koran Kompas tanggal 5 Januari 2018 tentang konflik ojek pangkalan dan ojek online di Bandung. Hasil analisis menyatakan bahwa konflik sudah dimulai sejak tahun 2010, kelompok ojek online hingga saat ini masih ditolak kehadirannya oleh kelompok ojek pangkalan yang menganggap bahwa kehadirannya merubah struktur sosial yang sudah terbangun sebelumnya. Alasan lainnya adalah adanya persepsi dan prasangka bahwa ojek online telah mengambil lahan penghasilan ojek pangkalan, sehingga pendapatannya menurun drastis. Faktor komunikasi juga memegang peran yang sangat kuat untuk menyelesaikan konflik antar kelompok yang berbeda budaya ini. Berbagai usaha dilakukan untuk meredam konflik ini terjadi, seperti kompromi, menghindar, namun tetap dibutuhkan sikap empati, toleransi, menghargai perbedaan dan mengembangkan komunikasi yang baik untuk menghindari kesalahpahaman.
\end{abstract}

Kata kunci: konflik, Budaya, ojek online, ojek pangkalan, teknologi 


\section{PENDAHULUAN}

Perkembangan teknologi di dunia saat ini sangat pesat dan tidak dapat dibendung di segala bidang. Teknologi tidak hanya dijadikan sebagai alat komunikasi, namun pemanfaatannya melebar ke aspek-aspek interaksi sosial lainnya seperti kesehatan, pendidikan, perdagangan, distribusi, perbankan dan transportasi.

Transportasi menjadi salah satu alat yang sangat penting yang digunakan dalam mobilitas kegiatan sehari-hari oleh masyarakat untuk bekerja, sekolah atau melakukan aktivitas lainnya. Kebutuhan akan transportasi ini meningkat tajam mengikuti peningkatkan jumlah penduduk dan fasilitas jalan raya yang tetap, sehingga banyak masyarakat yang mulai beralih menggunakan kendaraan umum yang dapat memberikan layanan jasa yang baik, aman dan terjangkau. Transportasi berarti memindahkan satu objek dari satu tempat ke tempat lainnya dengan menggunakan alat yang digerakan oleh manusia ataupun mesin.

Transportasi online mulai hadir di Indonesia diawal tahun 2010. Di Indonesia transportasi online termasuk terlambat dibandingkan Negara-negara lainnya yang sudah lebih dulu melakukan dan memanfaatkan transportasi berbasis online ini. Transportasi online sendiri merupakan jasa layanan transportasi yang mengandalkan Teknologi aplikasi yang digunakan untuk memesan barang dan jasa menggunakan sistem dan jaringan elektronik untuk menghubungkan konsumen. Perusahaan yang mengelola jasa transportasi online ini awalnya diatur dalam Surat Pemberitahuan Nomor: UM.3012/1/21/Phb/2015 tanggal 9 November 2015 yang dikeluarkan oleh Menteri Perhubungan Republik Indonesia, namun surat ini menuai kontroversial dan kemudian ditarik (Wijaya, 2016). Namun kemudian pemerintah melalui Menteri Perhubungan dan Komisi V DPR RI akhirnya resmi menerbitkan aturan regulasi terbaru mengenai transportasi umum, yakni melalui Peraturan Menteri Perhubungan (Permenhub) No. 32 Tahun 2016 tentang Penyelenggaraaan Angkutan Orang Dengan Kendaraan Bermotor Umum Tidak Dalam Trayek seperti taksi, angkutan sewa, carter, pariwisata, dan termasuk didalamnya layanan taksi online.

Data Badan Pusat Statistik menyebutkan jumlah sepeda motor pada tahun 2016 mencapai jumlah 98,88 juta unit (81,5\%). Diikuti mobil penumpang dengan jumlah 13,48 juta unit $(11,11 \%)$, kemudian mobil barang 6,6 juta unit $(5,45 \%)$, serta mobil bis dengan jumlah 2,4 juta unit (1,99\%) dari total kendaraan. (https://databoks.katadata.co.id). Hal ini menunjukan bahwa jenis transportasi motor ini sangat diminati oleh masyarakat di Indonesia. Sehingga potensi ini dilirik oleh Nadiem Makarim yang mempolopori pendirian ojek online yaitu Gojek yang kemudian diikuti dengan uber, grab dan lainnya. Dalam waktu yang sangat cepat transportasi ini menjadi sebuah bisnis layanan yang sangat popular dan diminati oleh pengguna transportasi. 
Ojek sendiri sudah ada sejak sekitar tahuan 1970-an. Kehadirannya pada awalnya adalah sebagai solusi transportasi di wilayah-wilayah yang tidak dapat dijangkau oleh transportasi umum seperti bis, angkutan umum. Penggunaan taxi jarang dilakukan diwilayah-wilayah terpencil dikarenakan tarifnya yang mahal. Ojek umumnya mereka berada di pelosok dan mangkal di tempat-tempat yang strategis. Pengemudi ojek kemudian perlahan meningkat sejak banyak pemutusan hubungan kerja.

Ojek online merubah merubah pola konsumsi penggunaan transportasi di masyarakat, yang selama ini menggunakan ojek konvensional/ojek pangkalan (opang). Kehadiran ojek berbasis teknologi menjadi salah satu solusi alternatif dan pilihan dalam memenuhi kebutuhan akan layanan transportasi tersebut. Ojek banyak digunakan karena menggunakan sepeda motor roda dua, sehingga cepat sampai ke tujuan. Identitas ojek online ini mudah dikenali dari atribut yang digunakan seperti seragam berwarna hijau, kemudian ketersediaan alat keamanan seperi helm dan masker serta tarifnya yang flexible tergantung jauh dekat jarak yang ditempuh serta penggunaan yang terekam dengan baik secara computerized sehingga menimbulkan rasa aman selain bisa di pesan dimana dan kapan saja. Hal inilah yang tidak dipunyai oleh pangkalan sehingga menyebabkan perpindahan pola konsumsi tadi. Belum lagi fasilitas penjemputan yang dilakukan ojek online ke tempat yang diminta tanpa adanya tambahan biaya.

Namun sayang kehadiran moda transportasi baru ini belum dapat berjalan dan diterima secara sepenuhnya oleh kelompok dalam masyarakat. Penolakan ojek online oleh transportasi kovensional seperti ojek pangkalan atau angkutan umum terjadi dimanamana. Gesekan akan budaya baru ini tidak hanya terjadi di kota besar namun meluas hampir ke seluruh wilayah di Indonesia yang ada ojek onlinenya. Konflik didasari antara lain karena adanya anggapan atau persepsi serta kecemburuan dari ojek pangkalan atau angkutan kota bahwa kehadiran ojek online sebagai penyebab kurangnya pelanggan yang berimbas kepada penurunan penghasilan yang mereka terima.

Konflik merupakan bagian dari kehidupan sosial dimana manusia sebagai objeknya. Namun konflik adalah proses menuju perubahan kearah baik positif maupun negatif. Hal ini dinyatakan oleh Para Ojek pangkalan merasa tersaingi dengan kehadiran Setiadi dan Kolip (2011) bahwa penyebab konflik adalah Perbedaan antar individu maupun kelompok seperti pendapat, tujuan, keinginan, ketidaksamaan mengenai objek yang dipertentangkan. Di dalam realitas sosial tidak ada satu individu yang memiliki karakter yang sama dan perbedaan karakter itulah yang memengaruhi dan memicu timbunya konflik sosial.

Hadirnya jasa ojek online berbasis aplikasi di Indonesia banyak mendapatkan tantangan oleh ojek konvensional atau ojek pangkalan, walaupun bisa menjadi alternatif permasalahan kemacetan dianggap mengurangi penghasilan mereka karena merebut pelanggan yang sebelumnya menggunakan jasanya. Seperti yang digambarkan dalam tabel kekerasan yang dihadapi oleh ojek online antara lain kekerasan verbal maupun fisik. 
Komunikasi lintas budaya menjadi sangat penting untuk melihat interaksi sosial yang terjadi diantara individu dan kelompok tadi. Dalam masyarakat yang majemuk, hal tersebut tentunya terdapat perbedaan-perbedaan dalam pemenuhan kebutuhan dan interaksi sosialnya. Nasrullah (2014) mengatakan bahwa hubungan sosial, akan terjadi interaksi antara individu dan individu, individu dan kelompok dan kelompok dengan kelompok. Sehingga interaksi yang dilakukan akan membentuk pola interaksi sosial dan identitas yang kemudian dijadikan sebagai aturan dan norma yang dipahami san disepakati secara bersama.

\section{Rumusan Masalah}

Permasalahan yang diangkat dalam makalah ini diambil dari Koran Kompas, Jumat 5 Januari 2018, pada halaman 23, dengan Judul, 'Konflik Transportasi. Warga Damaikan Ojek Pangkalan dan Ojek Daring', yang ditulis oleh Krisna Yogatama dan Dedi M. peristiwa ini sendiri terjadi di wilayah Arcamanik, Bandung.

Pada Koran ini dinyatakan bahwa sejak kehadiran ojek online, warga komplek Arcamanik Endah, Kelurahan Sukamiskin Bandung, sering merasa tidak nyaman. Penyebabnya bukan karena kehadiran ojek online itu sendiri, namun sering terjadi perselisihan antara ojek pangkalan dan ojek online. Warga setempat resah karena banyak menggunakan ojek online, namun layanannya sering diberhentikan oleh ojek pangkalan seperti adanya anak sekolah yang diturunkan ditengah jalan ketika menuju tempat didalam komplek, motor yang ditahan dan malah sudah menjurus kepada tidak kekerasan. Warga sendiri lebih banyak menggunakan ojek online sebagai pilihan dan mengatakan bahwa pilihan moda transportasi merupakan hak warga.

Menurut penulis konflik antar kelompok ini merupakan konflik antara budaya lama dengan budaya baru. Konflik merupakan sebuah hal yang tidak dapat dihindari. Konflik selalu mengarah kepada hal-hal yang tidak dapat dikomunikasikan secara baik dan tuntas. Menurut Samovar et all (2014), konflik ditentukan, diatur oleh budaya pada individu tersebut. Konflik terkadang terjadi dikarenakan keinginan untuk memertahankan identitas baik individu dan kelompok dari masing-masing individu. Proses konflik akan selalu bergantian dengan proses adaptasi. Keduanya akan saling memberikan kontribusi bagi sebuah perkembangan pembangunan, sebab sejatinya kedua proses ini akan berusaha untuk melengkapi apa yang belum ada, apa yang tidak sesuai dengan kondisi saat itu di lingkungan mereka berada serta untuk digunakan sebagai dasar perilaku selanjutnya.

Persepsi terhadap budaya pendatang baru seringkali menimbulkan ketidak nyamanan bagi budaya asli atau setempat ketika individu maupun kelompok tidak bisa menyesuaikannya, sehingga menimbulkan prasangka. Prasangka adalah perasaan negatif terhadap kelompok tertentu yang meliputi kemarahan, ketakutan, kebencian dan kecemasan, Prasangka akan selalu terkait dengan, sifat egois untuk memertahankan 
dirinya atau identitas yang sudah lama ada dan berdiam pada sebuah budaya (Samovar et al, 2014).

Identitas merupakan sebuah ciri yang ada pada tiap individu maupun kelompok, sehingga mudah dikenali. Ting-Toomey dan Chung (2005), berpendapat bahwa identitas sebagai konsep diri yang menggambarkan latar belakang budaya seseorang. Jika dikaitkan dengan kemajemukan di Indonesia, maka identitas menempel pada unsur budaya yang khas sehingga dapat dibedakan dari budaya lainnya. Berger dan Luckmann (1990), menyatakan bahwa identitas terbentuk melalui proses konstruksi secara terus menerus secara aktif oleh tiap individu dan masyarakat (Perdhani, 2017). Dari sini dapat disimpulkan bahwa setiap budaya akan melakukan penyesuaian ketika memasuki sebuah wilayah baru. Hal ini tidak hanya dilakukan oleh budaya pendatang, namun juga bagi budaya setempat

Jumlah yang kian banyak, dengan benefit yang banyak seperti harga murah, tarif promo, layanan antar jemput tidak hanya penumpang, namun juga pengiriman maupun pemesanan serta kemananan dan kenyamanan dari ojek online ini menyebabkan konsumen ojek online ini makin lama makin tinggi. Sulit sekali mengalahkan teknologi saat ini, yang tidak mampu menggunakan teknologi diyakini tidak akan memenangkan persaingan. Karena itulah diperlukan komunikasi lintas budaya untuk memahami bagaimana meminimalisir dan mengurani potensi konflik dengan penggunaan manajemen konflik serta proses adaptasi antar kelompok yang memiliki kesamaan jenis usaha namun berbeda dalam penggunaan teknologinya.

Dari uraian diatas mengenai konflik antara dua kelompok yaitu ojek pangkalan dan ojek online, maka artikel ini berkeinginan untuk mengetahui, membahas dan menganalisa secara literatur mengenai ojek online sebagai bentuk dari budaya baru yang ada di Indonesia, apa yang menyebabkan penolakan dari budaya konvensional (ojek pangkalan) terhadap ojek online, bagaimana cara mengatasi konflik dengan mengaitkan dengan manajamen konflik serta bagaimana proses adaptasi diantara kedua kelompok dalam menyelesaikan konflik?

\section{TINJAUAN PUSTAKA}

\section{Komunikasi Lintas Budaya}

Komunikasi lintas budaya adalah salah satu kajian dalam komunikasi untuk melihat bagaimana komunikasi dilakukan oleh individu ataupun kelompok yang berbeda budaya. Budaya menurut Purwanto (2011), merupakan kumpulan pengalaman hidup baik secara kolektif mapupun individu dan melekat secara perilaku pada diri invidu maupun masyarakat. Menurut Samovar et al (2014) budaya adalah pandangan manusia yang memiliki tujuan diantaranya mengajarkan kepada individu bagaimana manusia beradaptasi dengan lingkungannya. 
Komunikasi lintas budaya dimulai dari komunikasi antar pribadi (intercultural communication) yang dilakukan oleh individu atau kelompok yang mempunyai latar belakang kebudayaan yang berbeda (Liliweri, 2002). Budaya diyakini akan memberikan nuansa dan memengaruhi perilaku atas komunikasi yang dilakukan. Samovar et all (2014) mendefinisikan komunikasi lintas budaya sebagai interaksi komunikasi yang terjadi dari individu yang berbeda budaya. Sementara itu Purwanto (2011), mengatakan bahwa komunikasi lintas budaya adalah komunikasi yang dilakukan oleh minimal dua orang yang latar belakang dan geografisnya berbeda.

Budaya sangat memengaruhi proses komunikasi dan juga sebaliknya komunikasi juga akan memengaruhi budaya (Gudykunst dalam Rudd dan Lawson, 2007). Proses komunikasi melibatkan unsur-unsur sumber, pesan, media, penerima dan efek. Komunikasi lintas budaya diperlukan untuk meningkatkan pemahaman komunikasi, selain itu juga digunakan sebagai alat untuk melakukannya, karena jika gagal dalam melakukan komunikasi tersebut, maka akan ada resiko yang harus dihadapi. Menurut Devito yang dikutip oleh Teng (2009), terdapat tiga hal yang harus diperhatikan ketika mempelajari komunikasi lintas budaya yaitu:

1. Individu/kelompok yang berasal dari budaya yang berbeda akan melakukan komunikasi yang berbeda pula, sehingga

2. Dapat diketahui cara perilaku tiap budaya sebagai sebuah sistem yang arbiter, serta

3. Mengetahui dan memahami cara berpikir budaya lainnya yang berbeda

Terdapat tiga dimensi utama dalam komunikasi lintas budaya (Chen dan Starosta yang dikutip oleh Josephine, 2012), yaitu

a. Kesadaran lintas budaya (Cognitive/intercultural awareness) yang berkaitan dengan tingkat kesadaran budaya pada diri sendiri dan kesadaran akan adanya budaya lain di sekitarnya.

b. Sensitivitas lintas budaya (Affective/intercultural sensitivity), yang mengacu kepada kemampuan individu untuk mengembangkan emosi yang baik dan memahami serta menghargai perbedaan yang meliputi konsep diri, sikap nonjudgmental, keterbukaan dan relaksasi sosial.

c. Kecakapan lintas budaya (Behavioral/intercultural adroitness) yang meliputi ketrampilan dalam menyampaikan pesan, berperilaku sesuai kepantasan, dan berinteraksi.

\section{Identitas budaya}

Matthews (2000) didalam buku 'Komunikasi Lintas Budaya', Samovar et all (2014), menyatakan bahwa identitas merupakan proses bagaimana kita mengenali diri sendiri. Ting-toomey (2005) didalam buku yang sama mengatakan bahwa identitas mengacu kepada konsep diri yang merefleksikan gambaran dari mana kita berasal. Identitas merujuk pada pandangan diri ataupun bagaimana orang lain melihat kita. Dari pendapat 
diatas dapat dikatakan bahwa identitas menunjukan kepemilikan seseorang terhadap budaya atau kelompok tertentu.

Identitas dalam masyarakat multikultural menciptakan keberagaman. Chuang (2004), menyatakan bahwa identitas budaya individu akan menjadi kabur ketika bergabung pada masyarakat multikultural melalui proses integrasi budaya, pernikahan antar etnis, maupun melalui proses adaptasi (Samovar et all, 2014). Ketika kita melakukan berbagai kegiatan secara rutin maka identitas akan terbentuk, di bentuk dan ditampilkan secara berulang yang kemudian kaan dikomunikasikan dalam bentuk percakapan atau bentukbentuk aktivitas lainnya

Perubahan-perubahan dalam masyarakat tidak dapat dihindari akibat kemajuan ilmu pengetahuan dan teknologi, dan hal ini dikomunikasikan sehingga batasan-batasan budaya juga menjadi lebih luas. Pesatnya teknologi informatika komunikasi ini kemudian menjadi sarana difusi budaya dan menjadi alternatif dalam perkembangan budaya. Seperti yang telah disampaikan bahwa budaya bukan hanya sekedar tarian, lagu, bahasa, etnis namun budaya juga meliputi pola kerja, cara berintekasi, beraktivitas dan lain sebagainya.

\section{Manajemen konflik}

Konflik menurut Alisjahbana (1986) yang dikutip Romli (2014) adalah perbedaan pendapat dan pandangan diantara kelompok masyarakat untuk mencapai nilai yang sama. Konflik menurut Hendrik (1992) melalui 3 tahapan yakni adanya peristiwa, tantangan dan kemudian timbul pertentangan (Romli, 2014).

Konflik mempunyai konsekuensi positif dan negatif, namun jika konflik dapat dikelola dengan baik makan akan menjadi sebuat kekuatan yang bagus bagi pencapaian tujuan. Terdapat beberapa teknik-teknik pengelolaan konflik menurut Hardjana (1994) yang terdapat dalam buku Romli (2014) yaitu:

a. Bersaing (competiting): konflik yang mempunyai karakteristik mengorbankan pihak lain untuk mencapai tujuannya (win-lose approach)

b. Bekerja sama (collaborating): dimana kedua pihak yang berseteru terlibat kerja sama untuk mencari pemecahan konflik dan memuaskan kedua belah pihak (winwin approach)

c. Kompromi (compromising): penyelesaian konflik yang mengharuskan kedua belah pihak untuk saling memberikan kelonggaran pada masing-masing pihak (bisa win-win atau lose-lose approach)

d. Menghindar (avoiding): penyelesaian konflik yang dianggap tidak efektif karena masing-masing pihak hanya memperjuangkan kepentingan pribadi atau kelompoknya saja dan membiarkan konflik mereda dengan sendirinya. (lose-lose approach) 
e. Menyesuaikan (accomoding): pengelolaan konflik dengan melepas atau mengenyampingkan kepentingan pribadi atau kelompok dan memenuhi keinginan pihak lainnya. (lose-win approach)

Keberhasilan dalam menyelesaikan konflik sangat bergantung pada ketepatan dalam memilih dan mengelola tekniknya. Ditambah pula dengan kemampuan dan kesediaan pihak-pihak yang terlibat dalam konflik untuk menyelesaikan konflik yang terjadi

\section{Teknologi komunikasi}

Teknologi komunikasi merupakan sebuah media atau alat yang menggunakan internet untuk berintekasi dan mendapatkan informasi. Karakteristiknya adalah memiliki kecepatan akses yang sangat cepat. Seperti yang dikatakan pada bab pendahuluan bahwa teknologi merubah pola konsumsi manusia. Sebagai contoh misalnya komunikasi yang dilakukan melalui teknologi akan memudahkan manusia dalam mendapatkan akses. (Samovar et al 2014). Dampak positif dari teknologi komunikasi ini adalah dunia dapat diakses dengan cepat dan tidak berbatas. Waktu bukan lagi kendala ketika menggunakan teknologi. Sementara itu dampak negatif adalah teknologi ini dapat diakses oleh siapa saja, sehingga jika tidak dibarengi dengan kemampuan literasi yang baik dalam penggunaannya, maka akan menganggu perkembangan pola pikir yang ada karena semua informasi akan masuk tidak terbatas tanpa bisa dicegah.

Konsep ini digunakan dalam membahas konflik antara ojek pangkalan dan ojek online dikarenakan keberadaan ojek online adalah dengan menggunakan aplikasi berbasis teknologi. Untuk pemesanan dapat dilakukan dari mana saja dan kapan saja hanya dengan menggunakan perangkat teknologi. Jika diperhatikan ketika terjadi konflik biasanya kelompok ojek online akan langsung menghubungi anggota lainnya untuk segera bergabung dan membantu anggota lainnya yang sedang berkonflik.

\section{Persepsi/Prasangka}

Persepsi merupakan pengalaman mengenai objek, peristiwa atau hubungan yang diperoleh dari hasil menyimpulkan dan menafsirkan pesan (Rakhmat, 2011). Persepsi ditentukan oleh faktor personal dan faktor situasional. Ivancevich, dkk (2006) menyatakan bahwa persepsi adalah proses kognitif dimana seseorang individu memilih, mengorganisasikan, dan memberikan arti kepada lingkungan. Persepsi bisa didapatkan dari pengalaman melalui panca indra. Sehingga dapat dikatakan bahwa melalui persepsi setiap individu maupun kelompok akan merasionalkan ataupun menerjemahkan tentang orang atau lingkungan tersebut.

Prasangka merupakan perasaan negatif kepada orang atau kelompok lain. Perasaan menurut Macionis (1998) dikutip Samovar et all (2014), ini muncul bisa didasarkan pada sebuah fakta atau tidak ada bukti sama sekali. Semua manusia dapat menjadi target dari prasangka ataupun sebaliknya, semua orang dapat melakukannya.

Menghindari prasangka adalah sesuatu hal yang tidak mudah karena adanya aspek persepsi budaya yang memang sudah terbentuk dan ditanamkan melalui interaksi sejak 
kecil, namun prasangka dapat diminimalisir melalui pendidikan (Stephan dan Stephan, 2000) dan melakukan hubungan personal secara mendalam (Oskamp, 2000) yang dikutip oleh Samovar et all (2014). Hubungan personal diyakini bahwa semakin orang banyak berinteraksi maka dia akan lebih mengetahui dan memahami pihak lainnya.

\section{HASIL DAN PEMBAHASAN}

\section{Konflik ojek pangkalan terhadap ojek online dalam kajian teoretis}

Konflik antara ojek pangkalan dan ojek online sudah ada sejak dimulainya transportasi berbasis teknologi ini. Pada awal-awal konflik biasanya ojek online akan berusaha menghindari konflik (avoiding) dengan tidak menggunakan atribut seperti jaket ataupun helm dan beroperasi seperti ojek pada umumnya, namun tetap menggunakan aplikasinya. Penolakan terhadap ojek online terlihat seperti adanya plang-plang di wilayah tertentu. Berikut ini adalah contohnya:

Ojek online menurut penulis merupakan 'korban', karena mereka menerima order dari konsumen, namun ketika menjemput justru mereka yang dianiaya oleh ojek pangkalan karena dianggap mengambil konsumen dari wilayahnya. Hal ini juga di akibatkan adanya prasangka yang sudah ada sejak revolusi ojek online di Indonesia. Seperti diketahui bahwa prasangka menurut Samovar et al (2014) adalah perasaan negatif terhadap kelompok tertentu yang meliputi kemarahan, ketakutan, kebencian dan kecemasan. Dalam hal ini ojek pangkalan melihat kehadiran ojek online telah merebut konsumen di wilayahnya yang menyebabkan berkurangnya income yang mereka dapatkan. Belum lagi pelayanan yang diberikan oleh ojek online sangatlah baik.

Prasangka ini juga terkait dengan latar belakang dari tiap individu. Stephan dan Stephan, (2000) mengatakan bahwa prasangka adalah sesuatu hal yang tidak mudah karena adanya aspek persepsi budaya yang memang sudah terbentuk dan ditanamkan melalui interaksi sejak kecil, namun prasangka dapat diminimalisir melalui pendidikan (Samovar et al, 2014). Menurut penulis walaupun perlu dilakukan penelitian lebih lanjut, faktanya pengemudi ojek pangkalan mayoritas berasal dari pendidikan formal dasar, walaupun juga ada yang berasal dari tingkat yang lebih tinggi. Hal ini dapat disimpulkan bahwa pendidikan bisa memengaruhi pola pikir maupun pola interaksi yang dilakukannya seperti bagaimana menghargai perbedaan.

Dari sisi yang berbeda kehadiran ojek online dianggap merusak tatanan sosial yang sudah banyak terbentuk di ojek pangkalan. Penelitian dari Prasetya dan Legowo (2016), mengatakan bahwa tatanan sosial yang terbentuk itu adalah guyup, menggunakan sistem antri, solidaritas yang menunjukan budaya kolektivisme yang tinggi yang memang dianut oleh masyarakat di Indonesia. Budaya koletivisme sendiri adalah budaya yang selalu mengedepankan kepentingan kelompok. Gudykunst dan Lee (2003), menyatakan bahwa 
budaya koletivisme mengacu pada mendahulukan kepentingan kelompok dan sebagai imbalan anggota harus menjaga kelompoknya. Walaupun demikian jika melihat bahwa ojek pangkalan sering melakukan kenaikan harga sesukanya, maka kembali lagi apakah ojek pangkalan memiliki rasa empati atau solidaritas seperti yang ada pada budaya kolektivitas? Tidak, karena hal tesebut menunjukan keegoisan yang mementingkan diri sendiri. Sehingga tidak pula bisa dikatakan bahwa kehadiran ojek online merusak tatanan yang sudah ada. Kembali lagi tatanan sosial mana yang dirusak? Apakah tatanan secara umum atau tatanan yang memang dibentuk untuk menguntungkan kelompoknya saja.

Ojek online sendiri menurut penulis menganut dua budaya yaitu individualism dan kolektivisme. Budaya individualism digunakan oleh pengendara ojek online ketika ia sedang menjalankan bisnisnya. Sudah diketahui bahwa persaingan bisnispun sebenarnya sangat keras dalam dunia online. Tiap pengendara di perbolehkan mengambil konsumennya kapan saja dan dimana. Disini kecepatan dalam menerima order tergantung pada mau atau tidak si pengendara itu sendiri. Ini menunjukan bahwa karakteristis ojek online adalah mereka yang ambisi, mementingkan diri sendiri untuk keuntungannya. Namun ojek online mempunyai kelompok antara lain Persatuan Ojek Online Indonesia atau GERAM (gerakan aksi bersama-online Bandung Raya) . Jadi sebagai mitra dari organisasi pengelola aplikasi online, pengemudi ini merupakan bagian dari organisasi yang terikat oleh aturan, syarat dari pengelola ojek online. Namun sebagai anggota dari sub budaya dalam hal ini persatuan ojek online Indonesia, maka pengemudi ojek online juga akan mengedepankan kepentingan kelompok melalui komunikasi kelompok yang dilakukan.

Hal ini terlihat ketika terjadi konflik, walaupun terlihat individu namun dengan sangat cepat anggota ojek online yang lainnya akan segera datang dan bergabung yang membantu anggota ojek online lainnya yang mengalami kendala di lapangan. Anggota lainnya bisa segera mengetahui konflik melalui aplikasi yang mereka punyai tersebut.

Konflik yang terjadi bisa juga ditimbulkan akibat persepsi yang merupakan sesuatu yang ada dibenak seseorang yang diperoleh berdasarkan pengalaman terhadap objek atau peristiwa. Persepsi dapat dilakukan oleh semua pihak ketika melakukan komunikasi. Berikut ini perbandingan antara ojek online dan ojek pangkalan yang diolah oleh penulis dari berbagai sumber sebagai berikut:

Tabel 1.

Perbandingan ojek online dan ojek pangkalan

\begin{tabular}{|c|c|}
\hline Ojek konvensional & Ojek online \\
\hline $\begin{array}{l}\text { Harga tergantung kesepakatan. Bisa } \\
\text { berubah-ubah }\end{array}$ & Harga pasti mengikuti jarak tempuh \\
\hline $\begin{array}{l}\text { Standar keamanan tidak } \text { ada. } \\
\text { Penumpang tidak diberikan }\end{array}$ & Diberikan helm dan masker \\
\hline
\end{tabular}




\begin{tabular}{|l|l|}
\hline $\begin{array}{l}\text { Konsumen harus ke pangkalan untuk } \\
\text { naik ojek }\end{array}$ & $\begin{array}{l}\text { Fasilitas penjemputan tanpa dikenakan } \\
\text { biaya tambahan }\end{array}$ \\
\hline $\begin{array}{l}\text { Tidak menggunakan atribut, sehingga } \\
\text { tidak bisa diketahui apakah ojek atau } \\
\text { bukan }\end{array}$ & $\begin{array}{l}\text { Identitas dan atribut lengkap sehingga } \\
\text { bisa dipercaya }\end{array}$ \\
\hline Lebih flexible untuk berubah tujuan & Tidak bisa merubah tujuan \\
\hline $\begin{array}{l}\text { Ojek pangkalan dipersepsikan malas } \\
\text { dan tidak punya inisiatif karena hanya } \\
\text { menunggu penumpang saja }\end{array}$ & $\begin{array}{l}\text { Keamanan transportasi terjamin dengan } \\
\text { aplikasi yang terdata }\end{array}$ \\
\hline
\end{tabular}

Dari perbandingan diatas dapat dilihat ojek online sebagai gaya hidup baru saat ini suka atau tidak suka lebih banyak menawarkan benefit dibandingkan ojek pangkalan. Adanya persepsi bahwa ojek pangkalan lebih pasif dan bersifat menunggu penumpang saja menunjukan bahwa pengemudi ojek pangkalan adalah individu yang pemalas. Karakteristik diatas dapat dikatakan sebagai bagian dari budaya yang dimiliki oleh anggota ojek online. Budaya menurut Purwanto (2011), adalah sekumpulan pengalaman hidup yang tercermin dalam pemrograman kolektif dan melekat secara perilaku pada diri invidu maupun masyarakat. Atribut yang digunakan oleh ojek online merupakan cerminan dari pemrograman yang dilakukan secara kolektif yang kemudian menjadi satu bagian yang terintegrasi dan melekat ketika digunakan dalam berinteraksi secara sosial.

Senada dengan apa yang disampaikan oleh Ting-toomey (1999), bahwa terdapat beberapa faktor yang memengaruhi terjadinya sebuah konflik. Utamanya jika melibatkan sebuah kelompok maka umumnya yang berkonflik mempunyai latar belakang perbedaan dalam usaha pencapaian tujuan yang hendak dicapai oleh kelompok tersebut. Kasus ojek pangkalan dan ojek online ini memperlihatkan bagaimana tiap kelompok walaupun mempunyai tujuan yang sama yaitu kepentingan ekonomi namun cara dan usahanya dilakukan secara berbeda, dimana perbedaan itu disikapi dengan sifat persepsi curiga dan prasangka yang dinilai dari sisi dimana individu tersebut berada. Tingkat persepsi tersebut juga berbeda tergantung dari latar belakang individu dalam kelompok tersebut. Perlu diadakan penelitian lebih lanjut untuk mengukur keterkaitan persepsi dengan pendidikan dalam menghadapi konflik, namun penulis mempunyai hipotesa yang dapat disampaikan bahwa semakin rendah tingkat pendidikan (hanya diambil contoh 1 variable aja) maka tingkat persepsi (stereotype/ etnosentris) akan semakin tinggi, begitu juga sebaliknya semakin tinggi tingkat pendidikan maka tingkat persepsi (stereotype/ etnosentris) akan semakin rendah, karena dianggap akan lebih memahami perbedaan yang ada di dalam masyarakat.

Peristiwa di Arcamanik Bandung terekspos karena adanya aduan masyarakat kepada aparat. Ketua RW 013 komplek Arcamanik Endah mengatakan ada laporan dari warganya yang menggunakan ojek online diturunkan paksa oleh ojek pangkalan. 
Sebelumnya juga pernah terjadi kekerasan fisik. Warga setempat sendiri mengecam apa yang dilakukan oleh ojek pangkalan dengan membuat spanduk yang berisikan kecaman tindakan main hakim sendiri, padahal menurut warga pilihan moda transportasi adalah hak warga. Konflik dapat diatur oleh budaya dan terkadang terjadi karena adanya keinginan untuk memertahankan identitas masing-masing individu (Samovar et all, 2014). Jika merujuk kepada konflik yang terjadi maka dapat disimpulkan bahwa dalam konflik trasnportasi, ojek pangkalanlah yang masih menginginkan keberadaan dan identitasnya tetap ada sehingga tidak mau diganggu dengan kehadiran ojek online.

\section{Usaha dan Upaya Penyelesaian Konflik Ojek Pangkalan dan Ojek Online}

Seperti disampaikan bahwa menolak kemajuan teknologi sebagai bagian dari perkembangan budaya merupakan sebuah keniscayaan. Namun menghilangkan budaya yang sudah ada secara cepat juga bukan merupakan tindakan yang bijaksana. Berbagai usaha dilakukan untuk mencegah konflik yang terjadi. Tidak hanya oleh aparat dengan anggota ojek pangkalan maupun ojek online, namun juga partisipasi masyarakat dalam menyelesaikan permasalahan yang terjadi. Masyarakat ikut terlibat karena merekalah konsumen dari kedua moda transportasi tersebut. Masyarakat khususnya warga arcamatik dalam artikel dikoran menyatakan bahwa merasakan keuntungan yang banyak dengan kehadiran ojek online.

Usaha-usaha yang dilakukan seperti yang tertulis pada Koran Kompas adalah ada pertemuan pihak-pihak yang berkonflik dalam hal ini ojek pangkalan dan ojek online yang difasilitasi oleh aparat dan masyarakat pengguna jasa kedua moda transportasi tersebut dengan melakukan tindakan kompromi yaitu penyelesaian konflik yang mengharuskan kedua belah pihak untuk saling memberikan kelonggaran pada masingmasing pihak (Hardjana,1994) yang terdapat dalam buku Romli, 2014). Warga setempat menceritakan sejarah bahwa ojek pangkalan sebenarnya dibangun oleh masyarakat setempat ketika transportasi online belum ada. Sempat dibuatkan pangkalan dengan struktur organisasi. Saat itu ojek pangkalan juga diberikan tugas lain untuk menjaga keamanan. Namun proses ini ternyata tidak berjalan, tidak terkontrol sebagai mana mestinya akibat tidak adanya komunikasi antara pengurusn RW dengan pengurus ojek pangkalan, apalagi setelah pengurus RW berganti.

Pada pertemuan tersebut dihasilkan kesepakatan bahwa ojek pangkalan dan ojek online dapat beroperasi sebagai mana mestinya yang didasarkan pada konsep bersaing/berkompetisi secara sehat misalnya dengan berlomba-lomba memberikan pelayanan yang terbaik bagi konsumen. Kesepakatan lainnya ojek pangkalan dan ojek online melakukan bekerja sama (collaborating), dimana kedua pihak yang berseteru terlibat kerja sama untuk mencari pemecahan konflik dan memuaskan kedua belah pihak (win-win approach) (Hardjana,1994) yang dikutip oleh Romli, 2014). Kedua pihak yang difasilitasi oleh kepala Polsek Arcamanik menghasilkan 5 kesepakatan yaitu

1. Bersaing secara sehat 
2. Tidak ada lagi masalah antara ojek pangkalan dan ojek online

3. Membuat pertemuan rutin antara kedua pihak

4. Berbagai persoalan yang pernah terjadi dianggap selesai

5. Pengurus ojek pangkalan harus mengontrol anggotanya dan tidak berbuat anarkis di komplek Arcamanik Endah.

Jika mengacu kepada kesepakatan diatas maka hal ini seperti sapa yang disampaikan oleh Gudykunst bahwa budaya sangat memengaruhi proses komunikasi dan juga sebaliknya komunikasi juga akan memengaruhi budaya (Rudd dan Lawson, 2007). Proses komunikasi lintas budaya melibatkan unsur-unsur sumber, pesan, media, penerima dan efek sehingga komunikasi yang dilakukan akan memengaruhi cara individu untuk mengirim, menerima dan menafsirkan pesan dari dan ke individu lainnya dari latar belakang yang berbeda. Dari beberapa penjelasan mengenai komunikasi lintas budaya memunculkan sebuah asumsi apakah semakin besar tingkat perbedaan antar budaya, akan dapat menyebabkan hilangnya sebuah peluang untuk melakukan komunikasi yang efektif dikarenakan kemampuan proses adaptasi tiap individu yang berbeda.

Sejalan dengan pembahasan diatas, perlu juga memahami aspek-aspek berkomunikasi dengan budaya yang berbeda. Devito yang dikutip oleh Teng (2009) mengatakan bahwa perlunya manusia memahami bahwa budaya yang berbeda akan melakukan komunikasi yang berbeda. Ketika memahaminya maka kita akkan mengetahui pula cara berpikir dan berperilaku yang dilakukan oleh budaya lainnya. Hal inilah yang yang terjadi pada konflik transportasi ini. Komunikasi tidak hanya verbal tapi juga non verbal. Dalam konflik yang terjadi tidak menutup kemungkinan bahwa ojek online pun melakukan kegiatan komunikasi yang dianggap melewati batas-batas yang sudah dibangun sebelumnya oleh kelompok ojek pangkalan. Misalnya bisa saja ojek pangkalan, berprasangka bahwa ojek online sombong ataupun tidak sopan ketika melewati wilayah mereka.

Keahlian berkomunikasi dalam hal memanage konflik juga harus memperhatikan faktorfaktor lainnya seperti yang disampaikan oleh Chen dan Starosta yang dikutip oleh Josephine (2012), dimana harus ada kesadaran lintas budaya yang berhubungan dengan kesadaran budaya pada diri sendiri dan kesadaran akan adanya budaya lain, dalam hal ini ojek online sebagai budaya pendatang memperhatikan tidak hanya komunikasi verbal namun juga komunikasi non verbal seperti gesture tubuh, ekspresi wajah dan etika yang berlaku secara umum. Hal ini akan meningkatkan sensitivitas lintas budaya yang mengacu kepada kemampuan individu sehingga baik ojek online dan ojek pangkalan dapat mengembangkan emosi yang baik dan memahami serta menghargai perbedaan yang didukung dengan kemampuan dan ketrampilan dalam menyampaikan pesan, berperilaku sesuai kepantasan, dan berinteraksi.

Kemampuan adaptasi adalah kemampuan menyesuaikan antara kedua budaya yang ada Menurut Samovar et all (2014), konflik ditentukan, diatur oleh budaya pada individu tersebut. Konflik terjadi karena adanya keinginan untuk memertahankan identitas baik 
individu dan kelompok dari masing-masing individu. Proses konflik akan selalu bergantian dengan proses adaptasi. Keduanya akan saling memberikan kontribusi bagi sebuah perkembangan masyarakat, karena kedua proses ini akan melengkapi apa yang belum ada, apa yang tidak sesuai dengan kondisi saat itu di lingkungan mereka berada serta untuk digunakan sebagai dasar perilaku selanjutnya. Inilah yang sebenarnya terjadi pada konflik transportasi. Ojek online hadir untuk memenuhi kekosongan layanan yang belum pernah ada sebelumnya. Penolakan ojek pangkalan terhadap ojek online juga bukanlah suatu yang baik, apalagi saat ini untuk memenangkan persaingan dalam dunia bisnis, penyedia jasa layanan harus mampu memberikan pelayanan yang baik pula.

Dengan adanya pertemuan rutin yang digagas oleh aparat dan masyarakat setempat, maka diharapkan perbedaan persepsi, sikap curiga, kcemburuan sosial yang ada pada ojek online dan ojek pangkalan menurun intensitasnya atau bahkan membaur dan hilang, sehingga dapat menimbulkan budaya baru dalam hal ini akulturasi yang secara harfiah merupakan pertemuan dua budaya (ojek pangkalan sebagai ojek konvensional dari budaya yang lebih dulu ada dengan ojek online sebagai budaya pendatang) tanpa menghilangkan identitas dari masing-masing budaya mereka.

\section{SIMPULAN}

Dari pembahasan yang telah dijelaskan diatas maka kesimpulan yang dapat diambil adalah bahwa kehadiran ojek online merupakan rangkaian dari pemanfaatan kemajuan teknologi yang semakin canggih. Menolak teknologi rasanya tidak mungkin karena kita tidak dapat menghindarinya dan akan menyebabkan kemunduran karena tidak mampu bersaing. Perkembangan teknologi ini mengarahkan pada siapa yang mampu memberikan pelayanan yang lebih dalam produk dan jasalah yang akan menjadi pemimpin dalam bisnis.

Sebagai budaya pendatang kehadiran teknologi bukan tanpa hambatan. Moda transportasi online mengalaminya, sejak peluncuran pertama pada tahun 2010. Penolakan, kecemburuan, persepsi dari budaya yang lebih dulu ada sangatlah tinggi sekali, bahkan hingga sampai ke tahap konflik dapat terjadi secara terus-menerus. Sikap curiga muncul adanya persepsi dari budaya lama bahwa budaya baru dalam hal ini ojek online mengambil lahan mata pencarian mereka. Padahal ojek online justru berusaha mengisi dan melengkapi kekosongan yang terjadi pada aspek transportasi yang ada selama ini.

Peran komunikasi menjadi hal yang sangat penting untuk mempertemukan kedua budaya ini, karena proses komunikasi bukan hanya sekedar bertukar pesan, namun secara lebih luas merupakan proses interaksi sosial antar individu dan atau kelompok sosial yang mempunyai latar belakang yang berbeda. Membangun komunikasi lintas budaya bukanlah hal yang mudah, namun kesalahpahaman dapat diminimalisir dengan 
mengembangkan komunikasi yang baik dengan mengurangi sikap negative seperti prasangka ataupun curiga.

Walaupun sudah ada peraturan pemerintah yang mengatur tentang keberadaan namun perlu perhatian oleh pemerintah secara lebih mendalam. Hal ini disebabkan karena moda transportasi ini sudah menjadi gaya hidup baru di masyarakat Indonesia, sehingga perlu dipikirkan bagaimana membuat transportasi ini menjadi aman, nyaman tidak hanya bagi masyarakat pengguna namun juga bagi pengelola dan pelaku transportasi lainnya.

\section{DAFTAR PUSTAKA}

Gudykunst, William B \& Lee. 2003. Cross-cultural and Intercultural Communicaton. London: Sage Publications

Ivancevich, John M dkk,. 2006. Perilaku dan Manajemen Organisasi. Jakarta: Erlangga

Liliweri, Alo. 2002. Dasar-Dasar Komunikasi Antarbudaya. Yogyakarta: Pustaka Pelajar

Nasrullah. Rulli. 2014. Komunikasi Antar Budaya di Era Budaya Cyber. Jakarta: Kencana

Perdhani, Nathalia. 2017. Komunikasi Pariwisata, Budaya dan Pengembangan Potensi Daerah. (Kumpulan Prosiding Aspikom). Yogyakarta: Buku Litera

Purwanto, Djoko. 2011. Komunikasi Bisnis. Jakarta: Erlangga

Rakhmat, Jalaluddin. 2011. Psikologi Komunikasi. Bandung: Remaja Rosdakarya

Rudd, Jill E. dan Lawson, Diana R. 2007. Communicationing in Global Business Negosiations: A Geocentric Approach. UK: Sage Pub

Romli, Khomsahrial. 2014. Komunikasi Organisasi Lengkap. Jakarta: Grasindo

Samovar, Larry A, Porter, Richard E., Mc Daniel. Edwin R. 2014. Komunikasi Lintas Budaya. Jakarta: Penerbit Humanika

Setiadi, Elly M dan Kolip, Usman. 2011. Pengantar Sosiologi. Jakarta: Kencana

Teng, Loretta Ya-Wen. 2009. A Cross Cultural Communication Experience at Higher Education Institution in Taiwan.

Ting-Toomey dan Chung, L.C., 2005. Understanding Intercultural Communication. Los Angeles: roxburry Publishing

Wijaya, Andika. 2016. Aspek Hukum Bisnis Transportasi Jalan Online. Jakarta: Sinar Grafika 
Prasetya, Hendita Doni \& Legowo, Martinus. 2016. Rasionalitas Ojek Konvensional dalam Mempertahankan Eksistensi di Tengah adanya Gojek di Kota Surabaya. file:///C:/Users/User/Downloads/16556-20542-1-PB.pdf. Jurnal Paradigma Vol. 4 No. 3 tahun 2016

Josephine, Maria Elizabeth. 2012. Analisa Kompetensi Komunikasi Lintas Budaya dalam menyelesaikan Konflik Lintas Budaya. Jakarta: Universitas Indonesia

https://databoks.katadata.co.id/datapublish/2017/05/23/berapa-jumlah-kendaraanbermotor-di-indonesia

Permenhub

No.

32

Tahun

2016.

2016.

https://www.kaskus.co.id/thread/57eb8a8a582b2e82048b4567/permenhubno-32-tahun-2016-resmi-berlaku-oktober-2016-berikut-4-poin-pentingnya/ 